IDEA - Studia nad strukturą i rozwojem pojęć filozoficznych

\title{
AUTOPREZENTACJE
}

\author{
Rafał Włodarczyk
}

\section{STUDIUM Z FILOZOFII ERICHA FROMMA, KRYTYKI SPOŁECZNEJ I TEORII EDUKACJI}

\author{
Ideologia, teoria, edukacja. Myśl Ericha Fromma jako inspiracja dla pedagogiki \\ wspótczesnej, Oficyna Wydawnicza „Impuls”, Kraków 2016, s. 329.
}

Książka Ideologia, teoria, edukacja. Myśl Ericha Fromma jako inspiracja dla pedagogiki wspótczesnej proponuje szerokie odczytanie dorobku dwudziestowiecznego humanisty, mając przy tym na uwadze przede wszystkim problematykę teorii i praktyki edukacji, niemniej z racji przedmiotu podjętych w niej badań jest pracą interdyscyplinarną. Czerpie z dorobku, jak również stara się przekazać swój reinterpretacyjny impuls filozofii, socjologii, psychologii, naukom o polityce czy kulturoznawstwu, które jako punkty odniesienia dają się wyraźnie oznaczyć na mapie myśli i zainteresowań Ericha Fromma. Sama postać pochodzącego z Frankfurtu nad Menem badacza jest wciąż zaliczana do czołowych przedstawicieli humanistyki i nauk społecznych oraz świadków przemian i zjawisk zasadniczych dla XX wieku, co uzasadnia zaistnienie kolejnej, poświęconej mu monografii, a ukazujące się liczne przekłady, komentarze i powtórne wydania prac z jego blisko pięćdziesięcioletniego dorobku zdają się dowodzić, że 
nadal skutecznie przyciąga uwagę kolejnych pokoleń i budzi międzynarodowe uznanie. Można zatem uznać, że jest on nie tylko klasykiem cenionym za to, że na stałe wprowadził do intelektualnego obiegu pewne pojęcia i koncepcje, a jego prace, takie jak Ucieczka od wolności, Niech się stanie cztowiek, Zdrowe spoteczeństwo, O sztuce mitości oraz Mieć czy być?, współtworzą kanon lektur obowiązkowych. Konsekwentnie prezentowany w tych książkach obraz człowieka bywa odbierany i jako przenikliwy w swojej dociekliwości oraz kompleksowości, i jako w pewien sposób rażąco naiwny. W świetle uogólnień, do których doprowadzają frankfurtczyka jego prowadzone latami szczegółowe badania i praktyka psychoanalityczna, jest on z natury twórczy, konstruktywny, nie bez trudu i wyzwań dążący do harmonii $z$ samym sobą oraz otaczającym światem, a jednocześnie ulegający w wielu przypadkach zaburzającym jego rozwój wpływom niekorzystnego w ocenie Fromma stanu nowoczesnej cywilizacji i sposobu organizacji społeczeństwa, ale także konsekwencjom własnych decyzji. Mimo swej trudnej sytuacji współczesny człowiek zdaniem filozofa wciąż dysponuje wyborem. Stawką i jednocześnie alternatywą dla opisywanej przez badacza sytuacji jest rozwój potencjału tkwiącego w człowieku oraz sprzyjającego ludziom kształtu tworzonego przez nich ich własnego środowiska.

Co podkreśla wielu badaczy, prezentowana przez Fromma wizja natury ludzkiej i realizacji człowieka koresponduje z przyjętym w pedagogice humanistycznej, do której prekursorów jest zaliczany, pojęciem edukacji jako takim wspieraniem jego rozwoju, by w konsekwencji rozumiał on siebie oraz otaczający go świat, optymalnie wykorzystywał swój potencjał intelektualny i emocjonalny, jak również realizował swój byt w poczuciu podmiotowości i sprawstwa. Ideologia, teoria, edukacja potwierdza adekwatność i słuszność tego ujęcia założeń antropologicznych filozofa. Jednak jej wartość wykracza poza tę jedną perspektywę i zagadnienie. Prezentuje Fromma jako myśliciela odnoszącego się zarówno do swych żydowskich korzeni, jak również przedwojennych zaczynów działalności badawczej w kręgu szkoły frankfurckiej oraz zapoczątkowanej wtedy rewizji Freudowskiej psychoanalizy. Idąc tym tropem, rozwija poruszane przez Fromma zagadnienia w perspektywie krytycznej teorii edukacji i pedagogiki emancypacyjnej, do których ważnych źródeł zalicza się prace powstałe w Instytucie Badań Społecznych we Frankfurcie.

W latach trzydziestych XX wieku Fromm należał do czołowych postaci zatrudnionych w Instytucie, istotnie wpływał na kierunki prowadzonych tam prekursorskich badań i stawianych diagnoz społecznych, publikował artykuły pro- 
gramowe, wyznaczające drogi syntezy marksizmu i psychoanalizy. Jego odejście w atmosferze konfliktu z Instytutu zbiega się w czasie z publikacją przez Maxa Horkheimera i Herberta Marcusego artykułów, dających początek teorii krytycznej szkoły frankfurckiej, stanowiącej najważniejsze odwołanie dla niemieckiej i amerykańskiej pedagogiki krytycznej. Ponadto, wpływ filozofa daje się zauważyć również w Pedagogy of the Oppressed, niezwykle ważnej dla amerykańskiej pedagogiki krytycznej książce Paula Freirego, który współpracował w Meksyku z Frommem i Ivanem Illichem w czasie jej powstawania. Stąd odczytanie filozofii Fromma jako źródła inspiracji pedagogiki krytycznej, jak również pewna wariacja na temat teorii krytycznej, a zatem również krytycznej teorii edukacji wydaje się być uzasadnione. W książce zostają zrekonstruowane i przedstawione takie tematy prac Fromma, jak teoria społeczna, ideologia, problem alienacji jednostki i społeczeństwa, nieświadomości, ich uwarunkowań historycznych, emancypacji, krytyki społecznej, które stanowią charakterystyczne zagadnienia teorii krytycznej szkoły frankfurckiej, ale także wkraczają w pole zainteresowań innych dyscyplin humanistyki i nauk społecznych.

Nie chodzi jednak jedynie o pokrewieństwo między koncepcjami pedagogiki krytycznej i Fromma. W ostatnich latach czołowi przedstawiciele orientacji krytycznej w pedagogice polskiej, między innymi Zbigniew Kwieciński, Lech Witkowski, Zbyszko Melosik, Tomasz Szkudlarek, ale również Bogusław Śliwerski, Teresa Hejnicka-Bezwińska i inni, wskazywali na istotne wyzwania i zagrożenia związane ze zmianami, do których doszło w teorii i praktyce edukacji po transformacji ustrojowej. Wyrażali niepokój o perspektywy rozwoju człowieka, o racje oddziaływań na formowanie całokształtu jego zdolności życiowych w kontekście gwałtownych zmian społecznych i politycznych, przygotowanie ludzi do świadomego kreowania przyszłości w epoce upadku „wielkich narracji”, wielkich utopii i obietnic, o negatywne skutki pluralizacji teorii pedagogicznych ujawniające się zarówno w środowisku pedagogiki akademickiej, ale także w polityce oświatowej, o ucieczkę od wartościowania, zamiast troski o jego jakość, ale także o zdolność włączania się pedagogiki w podstawowe problemy i spory szeroko rozumianej humanistyki.

Stąd też stawiając sobie za zadanie analizę i pogłębione odczytanie dla pedagogiki i edukacji dorobku wybitnego zachodniego humanisty, omawiana książka kładzie nacisk na zawartą w jego pracach wizję emancypacji - realizacji pełnego rozwoju człowieka i zdrowego społeczeństwa wyrażoną w koncepcji radykalnego humanizmu oraz założenia teorii ideologii i jej krytyki, której rozwi- 
nięcie w monografii może pomóc w lepszy sposób rozumieć i badać tworzenie się kierunków i prądów pedagogicznych, a także ruchów społecznych oraz logikę osiągania przyszłych kształtów zamieszkiwanego przez nas świata za pomocą wysiłku edukacji. Wbrew potocznemu pojęciu ideologii, które nie zostało na gruncie pedagogiki dostatecznie sproblematyzowane, a następnie spożytkowane, zjawisko kryjące się za tym terminem jest bowiem rozumiane przez autora $P$ sychoanalizy a religii jako czynnik odpowiedzialny za realizację istotnej potrzeby człowieka oraz konieczny składnik życia, a przede wszystkim działania każdej zorganizowanej zbiorowości. Jego pogląd bliski jest podejściu wyrażonemu współcześnie przez Leszka Koczanowicza w pracy Polityka dialogu, kiedy zauważa on, że „Ideologia nie jest jedynie skrystalizowanym systemem przekonań i wartości, ale również sposobem, w jaki wyrażamy nasze poglądy w podejmowanych na co dzień działaniach”. Problem ideologii i krytyki społecznej obok kwestii związanych $z$ antropologią filozoficzną i pedagogiczną oraz koncepcją radykalnego humanizmu i zamysłu jego realizacji stanowią, zgodnie z główną linią argumentacji zawartej w książce, istotne zagadnienia nie tylko współczesnej teorii i praktyki edukacji.

Te trzy zagadnienia zostały analitycznie wyodrębnione w rozdziałach należących do części pierwszej monografii, poprzedzonych Wstępem oraz obszernym Wprowadzeniem, referującym recepcję dorobku Fromma na gruncie polskim, założenia metodologiczne pracy, a także związki koncepcji frankfurtczyka $z$ tradycją teorii krytycznej. Analitycznie, ponieważ wszystkie trzy wskazane zagadnienia w pracach filozofa są ze sobą ściśle powiązane, stanowią główne jej wątki, które przenikają całość jego pięćdziesięcioletniej pisarskiej pracy, prowadzonych badań i poszukiwań. W każdym z rozdziałów części pierwszej „Erich Fromm - analizy i odczytania” zostały wskazane kwestie i rozwiązania, jakie są istotne dla teorii i praktyki edukacji, oraz wyrażone w kategoriach, jak również osadzone w aktualnej wiedzy i prowadzonej dyskusji w polskiej pedagogice na temat podejmowanych zagadnień. Układ treści w każdym z tych rozdziałów jest podobny i obejmuje: prezentację problemu, odniesienie go do wybranych jego ujęć w pedagogice, następnie badanie zagadnienia w oparciu o całość dorobku intelektualnego Fromma wraz $\mathrm{z}$ uwzględnieniem kontekstu jego formowania (marksizm, psychoanaliza, tradycja żydowska) przy pomocy metod i technik właściwych hermeneutyce, a na koniec wskazanie na wynikające $z$ prezentacji, analizy i odczytania konsekwencje dla pedagogiki. Każde z podjętych w tej czę- 
ści pracy zagadnień wydaje się wykraczać w jakiejś mierze poza kanon odczytań obecnych w polskiej i zagranicznej recepcji prac filozofa.

Omówione $\mathrm{w}$ trzech rozdziałach części pierwszej zasadnicze zagadnienia myśli Fromma podejmują dyskutowaną w naukach humanistycznych i społecznych istotną, jak się zdaje, dla ich dziejów i rozwoju problematykę, z której korzysta teoria i praktyka edukacji, kształtując swoje pole wiedzy i działań. Stąd druga część pracy „Erich Fromm - konteksty i aplikacje” przynosi zawarte $\mathrm{w}$ dwóch rozdziałach badania w zakresie teorii ideologii i jej krytyki, mające na celu osadzenie dokonań intelektualnych Fromma i ich odczytania z jednej strony w kontekście historycznego kształtowania się pojęcia ideologii w europejskiej kulturze umysłowej oraz jego sposobów aplikacji na grunt pedagogiki, a z drugiej w kontekście modelu uprawiania krytyki społecznej, jaki inspiruje krytyczną teorię edukacji. Innymi słowy, w tej części książki podjęte zostało zadanie poziomej integracji wiedzy wytworzonej $\mathrm{w}$ teoriach naukowych $\mathrm{w}$ celu tączenia i konsolidacji wyników przeprowadzanych w monografii badań myśli Fromma $\mathrm{z}$ badaniami prowadzonymi w pedagogice ogólnej i jej naukach pomocniczych. Oba rozdziały tej części łączy zatem wspólna płaszczyzna, a określają ją dwa aspekty. Pierwszy dotyczy kwestii, w jaki sposób teoretyczna wiedza nauk pomocniczych inspiruje i warunkuje teorię pedagogiczną. Natomiast drugi tego, w jaki sposób odczytania koncepcji Fromma, które stanowią transfer wiedzy z nauk pomocniczych pedagogiki do pedagogiki ogólnej i krytycznej teorii edukacji, wzbogacają teorię i praktykę edukacji.

Wysiłki podjęte $\mathrm{w}$ całej pracy zostały zebrane w ostatnim rozdziale zatytułowanym „Wnioski i ustalenia - ideologia, azyl, edukacja”, poprzedzającym Zakończenie. Syntetycznie w trzech podrozdziałach omówione zostały w nim i uporządkowane główne zagadnienia prezentowane w poszczególnych rozdziałach książki, koncentrując się na inspirujących dla pedagogiki i edukacji zagadnieniach jego myśli, rekonstrukcji teorii ideologii i kryteriów jej krytyki oraz elementach jego filozofii dających się umieścić $\mathrm{w}$ polu problemowym pedagogii azylu.

Oczywiście realizacja podjętego w monografii zadania odczytania dla pedagogiki i edukacji dorobku Fromma obejmuje sobą również szereg innych ważnych zagadnień, takich jak: koncepcja natury człowieka, jego rozwoju, podmiotowości, zdrowia oraz ideału wychowania, koncepcja społeczeństwa i jego wpływu na kształtowanie się osobowości oraz zdolności życiowych człowieka, dialektyczna koncepcja zmiany społecznej oraz miejsca i roli w niej edukacji, 
teoria jednostkowej i społecznej alienacji i koncepcja emancypacji przez edukację, koncepcja ruchu emancypacyjnego, nauczyciela jako transformatywnego intelektualisty, utopii społecznej, doktryny pedagogicznej i ich powiązania w ideologii edukacyjnej radykalnego humanizmu, ogólnej teorii ideologii, koncepcji ukrytego programu edukacji oraz kryteriów ich krytyki, pedagogii azylu. Rozwinięte w pracy idee filozofii Fromma mogą poszerzyć naszą wiedzę i rozumienie teorii i praktyki edukacji, a jednocześnie przyczynić się do rewizji niektórych naszych poglądów oraz są alternatywne do interpretacji wskazanych tematów, jakie funkcjonują w pedagogice krytycznej i szerzej - w pedagogice ogólnej. Ponadto konsekwentna realizacja przyjętego zadania badawczego wymagała nie tylko rekonstrukcji, analizy i odczytania koncepcji Fromma, jej kontekstu filozoficznego oraz wpływu środowisk intelektualnego i kulturowego, z jakich się wywodzi, ale w kilku przypadkach również określenia, referowania czy wskazania stanu aktualnej dyskusji w pedagogice oraz poszczególnych dyscyplinach nauk humanistycznych i społecznych nad zagadnieniami, do których nawiązuje ten badacz w swoich interdyscyplinarnych z założenia pracach.

Ideologia, teoria, edukacja w dziejach polskiej recepcji myśli Fromma wydaje się stanowić pierwsze tego rodzaju studium. Od czasu wydania przekładu obszernego zbioru prac uznanego humanisty pod tytułem Szkice z socjologii religii sześćdziesiąt lat temu ukazało się kilka bardzo interesujących, godnych polecenia i ważnych opracowań jego filozofii, między innymi książki Mirosława Chałubińskiego, Kamila Kaczmarka, Macieja Kuci, Andrzeja Olubińskiego, Roberta Saciuka, Piotra Wasyluka i Zbigniewa Wieczorka. Omawiana monografia wiele zawdzięcza wkładowi polskiej, jak i zagranicznej recepcji, jednak w swoich zasadniczych tezach chciałaby móc pozostać na tym tle oryginalną. 